\title{
The Suggestions on Accurate funding for Ethnic Minority Poor University Students
}

\author{
Kun Wang, Daishan Mo \\ College of Management, Yangtze Normal University, China.
}

Keywords: Minority; Impoverished university/college students; Targeted funding.

\begin{abstract}
In recent years, China has introduced a series of funding support measures, which are characterized by greater efforts and a relatively perfect structure system, but those measures leave much to be desired in the targeted funding to minority university/college students. Such students are mainly from outlying districts and poor mountainous areas, where the socioeconomic development is below the national average, suffering from rather serious poverty, more in need of the patronage of national poverty alleviation policies. The survey finds that governments and universities/colleges at all levels have not put in place any mechanism of targeted funding to minorities, and always neglected the actual situations of minority students during the funding, so that quite a few impoverished minority students are not or inadequately funded.; it is urgent to establish a mechanism of targeted funding to impoverished minority university/college students, perfect the procedures of targeted funding to minority university/college students, increase the efforts of targeted funding to minority university/college students, conduct accurate identification and targeted funding to impoverished minority university/college students, cultivate high-level minority talents, and facilitate the overall poverty elimination in minority areas.
\end{abstract}

\section{Introduction}

Our impoverished university/college students have appeared after practicing the reform of tuition fee system for higher education, and become an increasingly prominent problem following the expenses for higher education to be borne partly by individual students and their families. In recent years, the Ministry of Finance, Ministry of Education and other ministries \& commissions as well as local governments at all levels have formulated a series of policies and measures to aid the university/college students from needy families, and the GSSL-dominated funding policy system for impoverished university/college students has been gradually improved, basically enabling those needy students enrolled in the public full-time regular universities/colleges to complete their studies successfully. Statistics show that in the 5 years since 2012, our nation has subsidized up to 425 million person-times, and aided 84.1384 million students in 2012 to 91.2614 million students in 2016, an increase of $8.47 \%$, and an annual average increase of $2.05 \%$; the funding standards are constantly rising from the national poverty alleviation amount for universities/colleges of RMB 112.608 billion in 2012 to RMB 168.876 billion in 2016, an annual average increase of $10.66 \%$. The existing financial aid policies to impoverished university/college students are featured by great efforts and a relatively perfect structure system, but those measures leave much to be desired in the targeted funding to minority university/college students. The minority university/college students are mainly from national autonomous areas or ethnically mixed areas, mostly remote and poor mountainous areas, where the socioeconomic development is below the national average, some minority areas are sunk in grinding poverty, with very serious poverty problems and extremely uneven socioeconomic development, and so they are more in need of the patronage of national poverty alleviation policies. Since our goal of building a moderately well-off society in an all-round way by 2020 solemnly put forward on the 18th National Congress of the Communist Party of China, the poverty alleviation has always been the national priority. At the 19th National Congress of the Communist Party of China, General Secretary Xi Jinping has even presented the targets to reinforce the support to minority areas, border areas and poverty-stricken areas for expedited development, persist in the targeted poverty alleviation and elimination, deeply implement the Chinese eastern and western collaboration for 
poverty alleviation, and emphatically overcome the poverty elimination in deeply poverty-stricken areas. Taking the author's Yangtze Normal University as an example, minority student's account for $30 \%$ of the total students in the University, characterized by a large proportion of impoverished minority students and a heavy poverty alleviation task. The accurate identification and targeted funding of impoverished minority students is an effective measure to solve these needy students, conducive to cultivating minority high-level talents, driving the all-round improvement of cultural and technological levels, and boosting the overall poverty alleviation of minority areas.

In the last a few years, with the increasingly improving financial aids to poverty-stricken university/college students and the "targeted poverty alleviation" concept proposed by General Secretary $\mathrm{Xi}$, the academic circles have made studies from different perspectives. In terms of the funding to university/college students, Tian S. (2014), Ning W (2014), Kang Y (2015) et al. have combined with reality to analyze the funding models to university/college students. Zhang Y (2015), Ma S (2017) et al. have analyzed the innovative working mechanism of targeted funding in universities/colleges. Wu F (2017), Zhang L. (2017), Wang Z H and Tong Y E (2017) have, from different theoretical perspectives, analyzed the reasons and present situations of universities/colleges or impoverished university/college students, and put forward the countermeasures and measures. Yang P, Tang Z B. (2016) et al. have analyzed the factors for the identification of poverty-stricken university/college students, and studied the funding models of universities/colleges to needy students.

The academic circles have conducted more theoretical studies on the reason analysis, funding model, working mechanism, etc. to impoverished university/college students, but not any research on the targeted funding to impoverished minority students; at present, governments and universities/colleges at all levels have always neglected the actual situations of minority students during the funding, so that quite a few impoverished minority students are not or inadequately funded. Impoverished minority university/college students are a widely concerned problem. It is based on such concern that this paper has analyzed the problems and status quo in terms of the mechanism, procedures and efforts of targeted funding to impoverished minority university/college students, carried out a deep survey oriented to the group of minority university/college students, and proposed appropriate countermeasures and suggestions to specific circumstances.

\section{Data Introduction and Analysis}

By using the documents related to impoverished student funding at home and abroad for reference, the "funding problem and status questionnaire of impoverished minority students" is designed based on the specific circumstances of impoverished minority students at a university in Chongqing. The questionnaire mainly includes the basic family information of minority students, their funded conditions, their satisfactions to the national and university/college funding policies and suggestions to the impoverished minority student funding, etc. Those minority students from the foundation year and the third year are given a questionnaire, supplemented by observation, interview and symposium etc.; among the 600 questionnaires distributed, 554 valid questionnaires have been collected, at an effective response rate of $92.3 \%$. On the basis of data collected from questionnaires, the survey data are processed to analyze the status quo and existing problems of funding to impoverished minority students.

\subsection{Status Quo and Causes of Poverty.}

Nowadays, our impoverished minority students suffer mostly from a large family population (90\% of impoverished minority students are from a family of 4-5 members), low annual household incomes (above RMB 30,000 accounts for $80 \%$ of total needy minority students) and a large proportion (around $80 \%$ ) of education spending in total annual household expenditure. Around $80 \%$ of respondents believe that the primary causes of poverty are chronic economic hardship in the family and high tuition pressure, plus the fact that minority students are predominantly from outlying poverty-stricken areas, and their parents are less educated, the overwhelming majority of whom are migrant workers or living off the land, subject to weak household labors and hardly increased family 
incomes. Around $60 \%$ of respondents think that poverty is mainly caused by too high tuition, increased living expenses year by year, in particular those overpopulated families, who are prone to poverty in case of any emergency.

\subsection{Analysis on the Status of FUnding.}

At present, $60.2 \%$ of students are funded, while $39.8 \%$ are not. It is mainly because the impoverished minority students are mostly of high self-esteem and inferiority complex, reluctant to confide, etc., always conceal themselves deliberately for the fear of being ridiculed, and thus abandon the application for joining the database of needy students in their universities/colleges. Besides, subject to the regional constraint, most of minority university/college students are from remote mountainous areas, with low family incomes, insufficient education spending, and their parents are often working away from home or less educated, always unable to apply for the poverty certificates at the civil affairs departments concerned following the current standards of recognition. Around 75\% of respondents have expressed their ideas to be funded directly by scholarship or grants and work-study posts; around $60 \%$ hope that they want to be funded by tuition waiver and subsidies, and only about $30 \%$ say that they want to be funded by loans in their origin and education funding. Thus, we can see that many students are expecting financial and material supports only to resolve their difficulties, in lack of initiative, aggressive and gratitude consciousness. So, universities/colleges should concentrate their efforts on fostering virtue through education.

\subsection{Expectations and Suggestions to the Funding.}

Table 1 shows that when understanding what further help are expected from universities/colleges and the society, around $80 \%$ of respondents have chosen to increase the quota of funding to impoverished minority students, more funding available and more work-study opportunities etc. Nearly $70 \%$ have chosen the tuition waiver. About $40 \%$ have chosen preferential policies to minority students and education funding. It can be seen that a vast majority of minority students are expecting more care and attention from their universities/colleges and the society.

Table 1.Expectations of impoverished minority students to funding

\begin{tabular}{|c|c|c|}
\hline Option & Subtotal & Proportion \\
\hline Tuition waiver & 372 & $67.09 \%$ \\
\hline Living subsidy & 395 & $71.43 \%$ \\
\hline More work-study opportunities & 432 & $78.06 \%$ \\
\hline More funding available for minority students & 399 & $72.11 \%$ \\
\hline To increased the quota of funding to minority students & 437 & $78.96 \%$ \\
\hline Preferential policies to minority students & 227 & $40.82 \%$ \\
\hline Education funding & 188 & $34.18 \%$ \\
\hline Others & 111 & $20.41 \%$ \\
\hline
\end{tabular}

Around $80 \%$ of respondents deem that policy standards should be made clear for equitable distribution of limited resources, so that the really needy minority students are funded effectively; it is essential to mobilize actively the social forces, strive for more social resources, and the governments, universities/colleges should increase the spending on education; it is necessary to contact external employers to provide more work-study and job opportunities. While $60 \%$ of respondents believe that the targeted funding mechanism should be specially oriented to impoverished minority students; it is required to establish a robust and efficient psychological aid system, in order to give psychological help to those impoverished minority university/college students.

Survey results show that the vast majority of students believe that minority students are mostly from backward and remote areas, suffering from underdeveloped economy, educational backwardness and widespread poverty-stricken families; it is worthy of attention whether different financial aid policies should be practiced specially for minority university/college students. Moreover, with a small population, the minority culture is also one of China's treasures, in need of inheritance by minority offspring; in this case, the national preferential policies specific to minority students may highlight the national attention to minorities. Secondly, most students think that the special funding policies to minority students may alleviate their schooling pressure, enabling them to 
be more engaged in learning; increased work-study posts may, to some extent, relieve their economic pressure.

\section{Problems in the Funding to Impoverished Minority University/College Students}

Besides the financial aids from national finance departments and universities/colleges, local governments at all levels should also combine with the local reality, employ a variety of aiding ways to increase the funding, particularly the implementation of targeted funding policies, for instance, Hu'nan, Yunnan, Qinghai and other provinces have made effective exploration to targeted funding, basically realizing the goal of "not letting a poor student be deprived of education"; however, various regions have not carried out the targeted funding to minority university/college students, mainly manifested in:

\subsection{Mechanism of Targeted Funding to Impoverished Minority University/College Students to Be Established.}

It is understood that the local governments and universities/colleges have not put in place the specific mechanism of targeted funding to impoverished minority university/college students, which may give rise to deformation and difference from what is intended in actual funding, etc. For example, when awarding grants, some universities/colleges fail to make differential funding, nor establish a policy or mechanism of targeted funding to impoverished minority university/college students; instead, they allocate the quota based on the number of students in the faculty, ignoring the characters, psychological features and territorial limitations of minority university/college students. Again, when formulating a scholarship policy, universities/colleges fail to make a difference, neglecting the differences in uneven basic educational resources, national culture difference, different information channels, etc. among impoverished university/college students from minority areas and the students from other regions; affected by subjective and objective factors, impoverished minority students are unable to be compared with students from developed areas, in spite of even harder acquired learning, there are still gaps in many aspects, which are actually unfair.

\subsection{Procedures of Targeted Funding to Impoverished Minority University/College Students Yet to be perfected}

The existing funding policy system of impoverished university/college students tends to be reasonable, with great funding efforts, able to provide the poverty-stricken students with equal access to education, playing a significant role in promoting the education equity, conveying the concern of the CPC and government as well as the warmth of our large socialist family. Nevertheless, in terms of identification of impoverished students, some universities/colleges are not objective enough in the verification of poverty status, less unified evaluation criteria and not accurate enough in the subjective evaluation, etc. For example, impoverished individuals are of varied poverty causes, plus the differences in regional economic development; thus, there is no horizontal comparability when each factor of poverty cannot be quantized in uniform and accurate weights. In general, it is very hard to distinguish accurately the rather impoverished from generally needy students during the identification, many universities/colleges are conducting evaluation mainly depending on the poverty materials submitted by such students and their first impression left on teachers and other students; moreover, the student grants are evaluated annually when freshmen are newly enrolled, teachers and students are unfamiliar with each other, it is difficult to judge accurately whether the students' poverty is true in the first impression. What the objective evaluation system of poverty status for impoverished university/college students lacks most is the evaluation links and steps for impoverished minority students.

\subsection{Efforts of Funding to Impoverished Minority University/College Students for Education Far From Enough}

First, the work-study posts in universities/colleges are limited, mostly of temporary jobs, with prominent imbalance between supply and demand. For instance, the author's University is located in New Urban District, which is in the initial development stage, the off-campus work-study posts are woefully inadequate, and of large mobility and management difficulty, adverse to the students' 
work-study in their spare time. The University has a large proportion of rural students, and a high percentage of poverty-stricken students, plus the increase with years of poverty-stricken students to be aided arising from being ill in hospitals, family emergency, etc., the temporary hardship grants and tuition waiver have failed to meet the students' needs, to be further given more support. Second, the funding work attaches more importance to the situation than to the effects, and more importance to the financial aid than to education; quite a few students have serious misunderstanding of "waiting, relying, requesting, scrambling" etc., and the subsidy funds have not brought into full play the due efficiency.

\section{Countermeasures and Suggestions on Targeted Funding to Impoverished Minority University College Students}

In the context of big push by the national funding policies, our universities/colleges have established perfect funding systems for student financing, but the financial aids to impoverished minority university/college students are to be established and improved from the following:

\subsection{To Establish the Mechanism of Targeted Funding to Impoverished Minority University College Students}

First, the mechanism of targeted funding should be established as a prerequisite and guarantee to ensure the institutionalization of targeted funding to minority students. Our country is in the period of accelerated development, poverty-stricken university/college students will still exist in a long time, the country, society, students and their families have increasing requests and expectations to funding, especially the funding to impoverished minority university/college students is even more long-term and arduous, to be carried out by a specialized agency and professional staff. Universities/colleges should improve working institutions and set up a special work leading group (WLG) for student funding. Vice-President in charge of student work should act as the group leader, Heads of Students' Affairs Office, Finance Office and other functional departments as deputy group leaders, and Secretaries of Party General Branch from subordinate colleges and Director of Student Support and Service Center as members, in full charge of student-financing management. A student funding organization should be established specially to organize and launch the student aids, forming the work system of vertical integration and concerted efforts where university/college leaders are responsible for overall management, functional departments for full coordination, and subordinate colleges for specific implementation. In line with the central government's strategic thinking of poverty relief, based on implementing the national and municipal government's policies of targeted poverty alleviation, the mechanism of accurate identification and targeted funding to impoverished minority university/college students should be explored by combining with the university-specific reality. It is urgent to formulate the special regulations on management of funding to impoverished minority university/college students, with any due help and aids available to minority poverty-stricken students. Second, it is essential to create a repository of impoverished minority university/college students, so as to accurately identify such students. "To eradicate poverty, we should extricate the poor from ignorance at first", "to help the poor, we should improve their education" and "do not let the children lose at the starting line” are General Secretary Xi Jinping's clear understanding and scientific judgment of dialectical relationship among poverty alleviation, education and development. Therefore, the funding targets should be precisely identified by all means. Without imposing a single solution, minority students should, by scientifically differentiating their origins, family difficulties and other objective factors, be funded in different grades to achieve the accurate identification of targets, precise use of funds, and precise time of release, subsidy funds should be applied sendibly to effectively resolve the students' pressing problems. It is necessary to change the prior broad irrigation into precise irrigation, fully comprehend the mindsets of funded students while funding, respect their personal privacy, keep the funding more humane, and cultivate their positive and optimistic characters. 


\subsection{To Improve the Procedures of Targeted Funding to Impoverished Minority University College Students}

The first is to develop an assessment plan and an indicator system of impoverished minority university/college students, thereby keeping the funding procedures precise. Some universities/colleges have adopted a single method to identify the poverty-stricken students, i.e. assigning the fixed quota to subordinate colleges, who have, in the absence of an indicator system to identify poverty-stricken students, identified such students only from their personal submittals and their initial impression left on the counselors and classmates, resulting in too many subjective assessment factors in the procedures. With regard to an indicator system for identification of poverty-stricken university/college students, the identification indicator system proposed by Dr. Wu Lixian from Fujian Institute for Education Research may be used for reference. The adjusted identification indicators include family background, basic information of students, origins of students, and counselors' assessment. The family background includes the family's economic resources, basic status of family members, special family conditions like whether the family has ever suffered from major disaster or significant misfortune, etc. The basic information of students includes their nationalities, native places, disabled or orphans and funded details. The origins of students include comments on their regions, local economic development levels and local minimum standard of living, etc. Counselors' assessment includes comments on the students' conspicuous consumption, inconspicuous consumption and comprehensive performance. Then the weight of each indicator is determined based on the opinions on the indicator system sought from the front-line funding workers and students at different grades by means of in-depth interview. Such students are scored via all indicators, the higher score, the more to be funded. The impoverished minority university/college students are differentially funded. Allowing for the fact that counselors are unacquainted with newly enrolled freshmen, they may take three-step procedures, that is, to know the family status by home visiting or video before enrollment of minority freshmen, carefully observe their dressing and make-up, baggage and equipment during the registration, and earnestly reviewing their materials after arrival, for the purpose of precise graded funding following the publicity level by level. The second is to utilize modern means of technological management and big data resources, establish and improve a funding subsystem or section to minority university/college students in the national student aid management information system, and boost the information sharing with student status, poverty relief, civil affairs and other departments, for accurate identification of funding targets. Giving full play to the objective and huge analysis of big data, a big data information technology platform can be used to collect the students' consumption information rapidly and efficiently, with the dining data of applicants' meal cards as an important indicator to analyze their conditions of consumption. By a funding system, online publicity, data review, information query, data verification, summery of reports, complaint reporting and other services can be handled, simplifying intermediate links; With such a subsystem, all-round information collection and processing can be carried out, and precise management of funding to impoverished minority students can be realized effectively.

\subsection{To Increase Efforts of Targeted Funding to Impoverished Minority University/College Students}

The first is to strengthen the construction of a funding policy system to improve targeted funding. Based upon the scholarship, grant, loan, work-study, tuition waiver and subsidy system with national loans for students and all scholarships \& grants as the basic guarantee and supplemented by special financial aids and temporary hardship grants, national scholarships and grants are adjusted to increase the proportion of national grants to the most needy minority students, and divide the grants into required funds and flexible funds. The required funds should be evaluated and awarded in accordance with the existing methods for evaluation and awarding of national grants. In addition, more funding sources should be sought actively from local governments, social enterprises and institutions, and good-hearted people for support to impoverished minority students, and such scholarships and grants should be taken as flexible funds, the use system of which should be established, followed by channels for rational utilizing. Impoverished students should be funded by paper comparison, work-study program, being involved in volunteering and social practice activities and other "paid" 
means, enabling them to develop a habit of getting paid for their work. For generally impoverished students, the proportion of encouragement scholarship should be increased so that the really needy students can be funded, and the generally impoverished students may strive for the encouragement scholarship by virtue of their academic records and daily performance. Benefiting from the temporary hardship grants and collective donations, students from affected families and sick students may get out of trouble, enabling those poverty-stricken students to feel truly their universities'/colleges' care and love. The second is to combine the funding with education. By building an "innovation base of funding for ideological and political education", the funding is combined with ideological and political education, to explore the educational function of funding, finding the model and method of funding for education. Meanwhile, commendation conference, thematic class meeting, and symposium and essay competition, etc. may be employed to publicize advanced models of inspirational talents, inviting the ever needy outstanding alumni to go back to universities/colleges to deliver a report and other colorful forms of education may also be adopted to strengthen university/college students' integrity and gratitude education, enable the funded students to cherish the hard-earned opportunities, stimulate them to always remember where their happiness comes from, study hard and strive to be better, facilitate their internalization of integrity and gratitude education into self-awareness and moral traits. Students are thus motivated to be enthusiastic, with solid confidence, use their own industrious work and wisdom to change their destiny and build a better future.

\section{Acknowledgements}

The authors thanks the support of Yangtze Normal University Research Funding Project, which is the Study on Poverty of Minority College Students in Southwest China (Grant No: 2016XJQN20).

\section{References}

[1]. Tian S. Issues and Countermeasures of Identifying Art Major Poor College Students [J]. Guide of Science \& Education, 2014.

[2]. Ning W. The Integration of Funding Aid, wisdom aid and Ability Aid: Poor Funding of College Students in Transition[C]// International Conference on Advances in Social Science, Humanities, and Management. 2014.

[3]. Kang Y. On the Theoretical Construction of Ability-funding for the Poor College Students [J]. Education \& Teaching Research, 2015.

[4]. Zhang Y. Quantification System of Poor College Students Identified-Take Southwest University of Science and Technology as an example [J]. Guide of Science \& Education, 2015.

[5]. Ma S, University L. Innovation and Discovery of the Funding Path for Poor College Students under New Situation [J]. Journal of Anshun University, 2016

[6]. Wu F. Construction of long-term mechanism of accurate identification and effective subsidization of poor college students [J]. 2016, 24:01012.

[7]. Zhang L. The Practice and Exploration of Accurate Finance Work for College students [J]. Journal of Hubei Correspondence University, 2017.

[8]. Wang Z H, Tong Y E. Exploration and Thinking on the Construction of the Precision Funding System for Poor Students in Higher Vocational Colleges [J]. Journal of Hubei Correspondence University, 2017.

[9]. Yang P, Tang Z B. Study of the accurate support model of poor college students [J]. Journal of Hunan Post \& Telecommunication College, 2018. 